\title{
Dar margen: teoría literaria, crítica e instituciones
}

\author{
y Juan Pablo Parchuc / Universidad de Buenos Aires - Conicet \\ jparchuc@filo.uba.ar
}

\section{Resumen}

Este trabajo propone una serie de discusiones e interrogantes sobre la relación entre teoría literaria, crítica e instituciones, a partir de la relectura de algunos de los elementos constitutivos de su historia como parte de la enseńanza y la investigación literaria en la Argentina. Se detiene en las nociones, usos y modalidades que han articulado la relación entre teoría literaria y juicio crítico desde mediados del siglo veinte $y$, en especial, entre los ańos setenta, ochenta y noventa, para analizar el vínculo contrastivo que produce su proceso de institucionalización con escenas y tramas que involucran tanto a la literatura como a otros saberes, prácticas y experiencias que suelen ser consideradas en los márgenes o la periferia de las disciplinas y especialidades que define el sistema científico y universitario.

Palabras clave: teoría literaria • juicio crítico • instituciones $\cdot$ borde $\cdot$ trama

\section{Abstract}

In this article I propose to consider a series of discussions and questions on the connection between literary theory and critique, reading some of the constitutive polemics of its history regarding the teaching and research of Literature in Argentina. I concentrate on the notions, uses and methods that have articulated this connection between literary theory and critical judgement since the middle of the twentieth century, and especially between the seventies, eighties and nineties, within the Departments of Literature in national universities, so as to analyze the contrasting relationship produced by the processes of its institutionalization through scenes and plots as they involve literature as well as other knowledges, practices and experiences that are usually considered to belong to the borders or periphery of disciplines and areas of specialization within the scientific and university systems.

Key words: Literary Theory $\cdot$ Critical judgement • institutions $\cdot$ border $\cdot$ plot 